structure $^{2}$ devised to explain the $5 \cdot 1 \mathrm{~A}$. meridian and the quantitative relations of the $\alpha \rightleftharpoons \beta$ transformation has been shown by Neurath ${ }^{18}$ to leave too little room for certain side-chains. The new $\alpha$-model has a simple structural basis, the close-packing of side-chains, which results in a square-stepped polypeptide chain of unit 5.1 A., thus yielding the strong meridian reflexion little dependent on side-chain weighting; that is, on chemical composition as such, but, of course, accounting only for the main X-ray features. This structure is stereochemically accurate and accords with many broad factors : a common principle for fibrous proteins, the right density for polymorphic transitions, a simple intramolecular stereoisomerism for the $\alpha \rightleftharpoons \beta$ transformation, correct distances for hydrogen bond backbone linkage between adjacent chains, and, of course, a closepacking of side-chains. In short, along the fibre axis we probably get a regularly spaced grating (period 5.1 A.) with its planes very regularly varying in reflecting intensity over a much larger (658 A.) period. A combination of this main structure and periodic fine structure to fit the experimental data is at present under investigation.

Provided the very regular porcupine quill fibre structure is not too disoriented by chemical treatment, the work of Speakman ${ }^{17}$ on the chemistry of the cross-links in wool invites the possibility of so chemically weighting selected residues as to promise their location by comparative analysis of the varying intensity distribution in the $(0 k 0)$ meridian series. Experiments with heavy metal and other atoms are in progress.

The fine periodicity is necessarily in size and reflecting power a function of chemical composition. The inter-linking of the keratin-myosin series thus depends on the standard skeleton, with the sidechain positions as sites, or by interchange of chains or grids-an intramolecular parallel to solid solutions. Keeping in mind the chemical relationships ${ }^{19}$, in $\mathrm{X}$-radiograms of the series we would then expect : (a) a standard effect on the intensities imposed by the common configurational feature; $(b)$ very similar fibre-axis periodicities ( $\sim 658 \mathrm{~A}$. as in quill); (c) the dominant (fairly large spacing) reflexions probably $2^{m} 3^{n}$ orders of this ; $(d)$ the particular $2^{m} 3^{n}$ orders similar for the keratin members, with slight intensity variation, but more markedly different for myosin.

This is largely borne out, as seen in Table 2, which gives some meridian reflexions obtained for various $\alpha$-keratin types together with measurements of an earlier (Astbury) fibre X-radiogram of dried sartorius muscle (frog) at 50 per cent extension. Especially for the latter, precision is not sufficient to determine macroperiods, and the strong $5 \cdot 1 \mathrm{~A}$. lines are taken as the 128 th order. Of the few reflexions that appear not to conform, three or four lines of a sharper nature in muscle (of which myosin is the principal constituent) are just those which clearly can be indexed as the chain cross-sectional reflexions of the fatty constituent or the prominent meridian arc associated with collagen.

Analysis proceeding will be reported elsewhere. What is important is that the keratin-myosin group of protein fibres is amenable even in detail to searching X-ray methods; that the new information already obtained for $\alpha$-keratin shows suggestively simple regularities in accord with those from quite other sources ; and that the results substantiate and can now check in detail the new $\alpha$-model which reconciles the broadest of protein characteristics and, while specific enough for quantitative treatment, is simple and accommodating in detail, as, of course, the biogenesis of proteins demands.

This work is being carried out under the direction of Dr. W. T. Astbury in the Textile Physics Research Laboratories, and under the joint auspices of the International Wool Secretariat and Department of Textile Industries, University of Leeds, to all of whom the writer offers his most cordial thanks.

\footnotetext{
${ }^{1}$ Astbury and Street, Phil. Trans. Roy. Soc., A, 230, 75 (1931).

2 Astbury and Woods, Phil. Trans. Roy. Soc., A, 232, 333 (1933).

${ }^{3}$ Astbury and Sisson, Proc. Roy. Soc., A, 150, 533 (1935).

4Woods, Proc. Roy. Soc., A, 168, 76 (1938).

- Astbury, private communication.

- Scott, Ph.D. Thesis, University of Leeds (1937)

${ }^{7}$ Corey and Wyckoff, J. Biol. Chem., 114, 407 (1936).

${ }^{8}$ MacArthur, Wool Rev., 9, (Jan. 1940).

- Astbury, Chem. and Ind., 60, 491 (1941).

${ }^{10}$ Astbury, J. Chem. Soc., 337 (1942).

${ }^{1}$ Astbury and Preston, Nature, 133, 460 (1934).

12 Astbury and Marwick, NATuRE, 130, 309 (1932).

${ }^{13}$ Müller, Proc. Roy. Soc., A, 138, 514 (1932).

16 MacArthur, unpublished.

is Bernal and Fanktchen, J. Gen. Physiol., 25, 147 (1941).

is Shearer, Proc. Roy. Soc., A, 108, 655 (1925).

17 Speakman, for example, Mather Leeture, J. Text. Inst., 32, 3 (1941).

${ }^{18}$ Neurath, J. Phys. Chem., 44, 296 (1940).

to Compare review by Astbury, J. Chem. Soc., 337 (1942).
}

\section{THE ISLAND OF NEW GUINEA*}

\section{By L. Evelyn Cheesman}

$\mathrm{T}$ HIS huge tropical island is only partially explored. Even the coasts are not yet thoroughly and accurately charted, and though there are few large areas of the vast hinterland entirely unknown, only the main topographical features have been named and located in an approximate position. Early records, too, need to be checked; this was proved by one of the Papuan patrols, which found a large lake where the Arthur Gordon Range was supposed to be. The traveller is, therefore, always inadequately equipped for penetrating what is for the most part an exceptionally difficult type of country, whether it be mountains or swamps.

The early geological history of New Guinea can only be indefinitely conjectured since there has never been a general survey. Briefly, it can be summarized thus : Palæogeologists postulate a large land mass, which they named Palæonotis, as having extended from Asia to Australia during the Middle Cretaceous period, and extending as far as New Caledonia, and westward to Sumatra and Java. Some time during the Early Eocene, part of this land broke away from the Australian shelf and later submerged. From this submerged land mass the great folding movements of the Miocene-Pliocene periods raised the high central mountain system of New Guinea. During the next epoch connexion with the Philippines sank, and the island took form as we know it to-day. A more recent connexion with Australia is supposed to have taken place in the Late Pliocene, when the Torres Strait was dry for a relatively short period, allowing the marsupials and other Australian groups of plants and animals to migrate to New Guinea.

It would be thought that geologically young land

- Substance of a Friday discourse at the Royal Institution delivered on May 28. 
raised from the sea, its sole continental connexion being with Australia, would possess a fauna and flora basically Australian; also that these would be incomplete with many gaps in the groups. On the contrary, New Guinea has continental fauna and flora, of Asiatic origin, with no serious gaps in the totality of groups such as to suggest population by temporary land bridges. The suggestion is rather that there was connexion with an older fully populated land. There is a strong Australian element, a Malaysian element, and a weak South American element which could have been introduced via Australia.

A possible explanation is to be found north of New Guinea, where are remnants of very ancient mountain ranges, some of pre-Cambrian rock, on an alignment parallel with that of the main ranges. These are : the west coast of New Britain, the Finisterre and Torricelli Ranges, Mt. Oinake, the Cyclops Range, Japen and Waigeu Islands. Supposing these to be part of an old land mass, populated from Asia, which remained above water long enough to colonize the young land of New Guinea as it rose from the sea, this would account satisfactorily for the origin of the Papuasian flora and fauna, which are characterized by a very rich neo-endemism, indicating isolation over a long period.

The Papuasian faunal sub-region includes adjacent archipelagos, the Solomons and New Hebrides archipelagos and New Caledonia.

It is interesting to note in connexion with the above that the Cyclops Range, of very ancient preCambrian rock and old crystalline schists, shows no indication of submergence; no maritime deposits have ever been recorded from the mountains. Another interesting fact emerges from records by geologists of an Australian oil company working in this region for fifteen years, who found evidence of tectonic movements still proceeding in the Torricelli Range.

Reef limestone belonging to many periods and exhibiting an endless variety in formation occurs throughout New Guinea from the coast to high mountains. The formidable "limestone barrier", crossed by Karius and Champion in 1928 between the sources of the Fly and the Palmer Rivers, is described by them as consisting of series of pits of varying sizes, some as much as $100 \mathrm{ft}$. in circumference, with pinnacles and knife-edged ridges between them. What is probably a similar type of formation appears on Waigeu and also on Japen. On the former island, series of small narrow ranges of about a thousand feet in height have built up the eastern shore of Mayalibit Bay. Between these ranges are very deep clefts almost to sea-level, the ridges are castellated, of rough sharp-edged rocks, with deep pits between the peaks--most dangerous to regotiate especially when screened by vegetation.

Sea erosion produces curious three-sided cylindrical clefts in limestone cliffs, as on the north side of Oinake Massif on the boundary between Dutch and British Territories. One example on Djoea Bluff between $200 \mathrm{ft}$. and $300 \mathrm{ft}$. high pierces a cliff to the beach.

Volcanic intrusion occurred in the north of New Guinea ; a few volcanoes are still active on the coast. In 1933 a violent earthquake wrecked the Torricelli Range. This ranks with the world's most severe earthquakes. So late as 1939 the northern slopes were still bare precipices, quite an arresting sight in that luxuriant forest; valleys were still choked with rocks, rivers were forming new channels, and huge tree trunks, still standing, have been split and twisted in a peculiar fashion as if wrenched by a giant fist.

There is not so much variation in temperature as might be expected; the thermometer registers $74^{\circ}-$ $84^{\circ} \mathrm{F}$. up to an altitude of $3,000 \mathrm{ft}$. Above this the temperature falls a few degrees; $38^{\circ}$ at night has been recorded at $10,000 \mathrm{ft}$. On the highest moun. tains, 16,000 ft., snow and frost occur. Carstenz Top, 15,709 ft., has large glaciers.

Rainfall is extremely heavy over nearly all the island, but varies very greatly in localities. There are two seasons marked by the north-west and southeast monsoons. Dry areas or savannahs with characteristic vegetation occur contiguous with high rain forest. They are accounted for by the alignment of mountain ranges. Where strong rain-laden winds blow parallel with ranges, areas on each side are drier, and where high mountains obstruct the passage of these winds, there is a very heavy rainfall. Thus, Port Moresby at the end of one savannah has an annual rainfall of 32 in., while the government station of Kikori at the farther end among high peaks has 232 in.

The savannahs are distinct from areas deforested by natives to make their villages, on which a secondary vegetation replaces the forest, principally of plants and trees of rapid growth, and species with a very wide distribution. There are many such areas, especially on mountains where a large native popula. tion has flourished, which has either died out or moved to another locality. Even the alpine grassland of high mountain tops where are no native villages is disturbed by human agency, being often partially destroyed by the fires of native hunters.

New Guinea is fortunately outside the cyclone zone, but is subject to very high winds, gales, squalls and cyclonic disturbances. In Papua occur sudden very violent squalls known as gubas. In Netherlands New Guinea in the first week of October, gales from the north-west called wambran blow with terrific force for eight or ten days, after which they subside as suddenly as they began. It is an uneasy experience to be among the mountains during this period. Hundreds of trees are blown down; there is no adequate shelter from torrential rain except rock caves, for the rain is driven horizontally. Nothing can be seen but steamy white clouds being carried by with an amazing velocity, or the grey, driving sheets of rain. Coastal tribes recognize by certain signs, such as brilliant sunsets, the approach of the wambrau; canoes race to shelter and are drawn up on beaches. The south-east of New Guinea does not experience these gales, but apparently (according to verbal reports) they are felt at the same date north of the Papuan Gulf, and they probably blow across a wide zone of the centre of the island except where high mountain masses intervene.

The native population is Papuan-Melanesian, characterized by stiff, kinked hair, which gave them the early name of Papoo, that is, "fuzzywigs". Several influences can be detected which result in a considerable variation in build, skin colour, and facial features, as well as character of the hair, which is fine and straight or waved in true Melanesians and Malaysians. In some tribes the skin is definitely lighter in colour, with a bronze tint.

True pigmies exist, mainly in high mountain regions, where they are thought to have taken refuge from stronger, aggressive tribes. In certain districts are small Negritto-Papuans, resulting from some 
crossing of types not clearly understood, and presenting variations in size of adults even in one family.

Within the last ten years, gold prospectors made discoveries of densely populated areas in the highlands of the Mandated Territory which had always been supposed to be sparsely inhabited. These tribes had evolved an extremely interesting and advanced type of agriculture.

Head-hunting and cannibalism certainly are still practised, but such customs are becoming rarer. As Papuans come in contact with more advanced peoples, public opinion among themselves is apt to change, and such barbarous practices are deprecated and will finally be voluntarily abandoned.

All Papuan tribes fall into two categories, they are either people of the forest or people of the sea. From babyhood they are taught to observe every landmark, changes in the sky with nuances of which we are scarcely conscious; all have distinctive names, as also all living things however small. Frequently there are different names for the two sexes, even of insects. Sea people are as unhappy when away from the coast and as terrified of mountains as forest people are unhappy in coastal areas and terrified of the sea.

With its rich tropical vegetation, New Guinea is surprisingly poor in natural products to support human life. The indigenous population flourishes only where animal or fish diets are plentiful. Some tribes appear under-nourished. Among vegetables cultivated in native gardens the introduced sweet potato is of good food value; the same cannot be said of other roots, taro and yam. Sweet potato alone can sustain white men in good health; this was proved by Champion and Anderson in the BamuPurari Patrol, 1936. Sago, which is the main food of many tribes, is not a white man's diet; it is indigestible and has no energizing value; this was proved by the Karius-Champion Patrol of 1928.

Papuans are extremely primitive, with a Stone Age mentality. Individuals exhibit a marked intelligence, but few outside influences appear to make lasting impressions. When working with white men, opportunities for mastering machinery or for learning storekeeping, mining, etc., may arouse latent ambitions, and the Papuan proves reliable and independent, although in most cases his acquirements are parrotwise without undue reference to his reasoning powers. For the Papuan exists almost entirely subconsciously ; his entire being is not only associated but also closely interlocked with all objects-human, superhuman, animate and inanimate-which compose his natural surroundings. His instinctive reactions to his outside world are scarcely comprehensible to those guided by reason; his power of self-suggestion is unbridled, so that death may be caused by a paroxysm of fear of something entirely imaginary. Control of his own vitality exists to an astounding degree. This mental attitude of Papuans must be realized by those who have any dealings with them, for thus many tragedies may be avoided. Belief in the supernatural is fundamental ; it cannot be eradicated ; and no other beliefs are sufficiently interesting and stimulating to be substitutes.

Scientific collections from New Guinea have been augmented of late years, due to the efforts of scientific societies and of individuals. Most valuable collections have reached the United States from the Richard Archbold Expeditions, particularly from the latest, 1937-38, when systematic collecting was carried out at different altitudes on the highest mountains of Netherlands New Guinea. A flying-boat is used as transport on these expeditions. Air transport is undoubtedly the solution to all difficulties of collecting on that island, and where the financial aspect need not be considered, should definitely be adopted.

\section{NEWS and VIEWS}

\section{Royal Society of Arts : New President}

Dr. Edward Frankland Armstrong has been elected president of the Royal Society of Arts, of which he has acted for a number of years as treasurer. Dr. Armstrong is highly qualified to occupy this distinguished position, for he is a man who has not only made valuable contributions to scientific research in many fields of pure chemistry, both organic and physical, but has also held many high positions in the world of industrial chemistry, where his influence and guidance have led to important advances. As one of the small band of men who worked with the great van't Hoff during his sojourn in Berlin, Dr. Armstrong was successful in clearing up the phase transformations and equilibria of calcium sulphate and its hydrates, a problem which had greatly puzzled van't Hoff and some of his earlier collaborators.

During the period (1915-19) when Dr. Armstrong was managing director of Joseph Crosfield and Sons at Warrington, he carried out in collaboration with his chief chemist Hilditch (now Campbell Brown professor of industrial chemistry at the University of Liverpool) an important and pioneering series of researches on the catalytic hydrogenation of oils and fats. $\mathrm{He}$ has also done valuable original work in the field of carbohydrate chemistry, and is the author of well-known monographs on the simple carbohydrates and the glycosides. Apart from the numerous high industrial and administrative positions which he has held, his wide experience as president of the Society of Chemical Industry (1922-24), chairman of the British Association of Chemists (1926), chairman of the Association of British Chemical Manufacturers $(1930-33)$, and chairman of the British Standards Institution (1934-35) will be of great value to the Royal Society of Arts.

\section{Royal Society of Edinburgh: Honorary Fellows}

THE following have been elected honorary fellows of the Royal Society of Edinburgh :

F'oreign Fellows : Prof. G. D. Birkhoff, professor of mathematics, Harvard University; Dr. H. S. Gasser, director of the Rockefeller Institute, New York; Dr. D. Emilio Jimeno Gil, rector of the University of Barcelona ; Prof. Thore G. Halle, Naturhistoriska Riksmuseum, Stockholm; Prof. H. S. Jennings, Walters professor of zoology and director of the 